\title{
Association of Urinary Tract Infection and Ultrasonographic Finding of Bladder Debris in Pediatric Patient
}

\section{Çocuklarda Ultrasonografide Saptanan Mesanede Debris Bulgusunun Idrar Yolu Enfeksiyonu Birlikteliği}

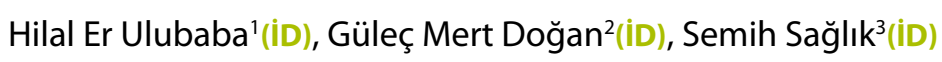 \\ ' Clinic of Radiology, Yesilyurt Hasan Calik State Hospital, Malatya, Turkey \\ ${ }^{2}$ Department of Radiology, Inonu University School of Medicine, Malatya, Turkey \\ ${ }^{3}$ Department of Radiology, Private Hayat Hospital, Siirt, Turkey
}

\begin{abstract}
Cite this article as: Er Ulubaba H, Doğan GM, Sağlık S. Association of urinary tract infection and ultrasonographic finding of bladder debris in pediatric patient. J Pediatr Inf 2019;13(4):e153-e157.
\end{abstract}

\section{Abstract}

Objective: Early diagnosis and treatment of urinary tract infections (UTI) in children has clinical importance since the signs and symptoms can be nonspecific. The aim of this study was to investigate the association between bladder debris which is commonly seen at the process of ultrasonography (USG) and positive urine culture in pediatric patients that will alert the clinicians in the diagnosis of UTI when the signs and symptoms are nonspecific.

Material and Methods: A retrospective analysis of pediatric patients who underwent USG examination between February 2017 and February 2018 was conducted. USG reports were analyzed from the aspects of layering and floating debris. Patients who were formerly diagnosed and treated for urinary tract infection (UTI) and patients who had genitourinary system abnormalities (Hydronephrosis, Vesicoureteral Reflux, neurogenic bladder etc.) was excluded from the study. In the 0-11 age group, we detected 93 patients suffering from debris, who also had urine culture. These patients were compared with 50 patients in the control group in the same age group, who had normal USG and urine culture.

Results: Ninety-three patients with bladder debris were classified under two groups as layering and floating debris. In Group 1, there were 21 patients with layering debris and there were 72 patients with floating debris in Group 2. Control patients group consisting of 50 patients was referred to as Group 3. According to multiple logistic regression analysis, a statistically significant increase was detected at the rate of positive urine culture in patients with layering debris (Group 1) and patients with
Öz

Giriş: Çocuklarda idrar yolu enfeksiyonunun erken tanı ve tedavisi önemli olup küçük çocuklarda nonspesifik bulgulardan dolayı klinik tanı zorlaşmaktadır. Bu çalışmanın amacl; çocuk hastalarda ultrasonografi (USG) sırasında rastlanan mesane debrisinin, pozitif idrar kültürü birlikteliğini araştırıp idrar yolu enfeksiyonu (IYE) tanısına katkısını saptamaktır.

Gereç ve Yöntemler: Şubat 2017-Şubat 2018 tarihleri arasında USG yapılan çocuk hastaların retrospektif incelemesi yapıldı. USG raporları mesanede seviye oluşturan ve seviye oluşturmayan debris açısından incelendi. Daha önce IYE tanısı ve tedavisi alan hastalar ile genitoüriner sistem anomalisi olan hastalar (hidronefroz, VUR, nörojen mesane vb.) çalışma dışında tutuldu. Yaşları 0-11 arasında olan 93 tane idrar kültürü (IK) bulunan debrisli hasta tespit edildi ve aynı yaş aralığında USG'si normal olup idrar kültürü çalışılan 50 tane kontrol hastasıyla karşılaştırıldı.

Bulgular: Mesanede debris bulunan 93 hasta seviye olup olmamasına göre iki gruba ayrıldı. Grup 1'de 21 tane seviye oluşturan debrisli hasta mevcuttu. Grup 2'de ise 72 tane yüzen debrisli hasta vardı. Elli hastadan oluşan kontrol hasta grubu ise grup 3 olarak isimlendirildi. Multipl lojistik regresyon analizine göre; seviye oluşturan debrisli hastalarda ve yüzen debrisli hastalarda kontrol grubuna göre pozitif idrar kültürü oranında istatistiksel olarak anlamlı artış saptandı. Ancak seviye oluşturan debrisli hastalarda + IKK oranındaki artış daha yüksekti.

\section{Correspondence Address/Yazışma Adresi}

Hilal Er Ulubaba

Yeşilyurt Hasan Çalık Devlet Hastanesi,

Radyoloji Kliniği,

Malatya-Türkiye

E-mail: erhilal44@yahoo.com 
Er Ulubaba et al.

floating debris (Group 2) compared to control patients (Group 3). However, increase at the rate of positive urine culture (UC) was higher in patients with layering debris.

Conclusion: Statistically significant increase at the rate of positive urine culture (UC) was seen in the pediatric patients who had bladder debris at ultrasonography. The increase in patients with layering debris is higher. In the pediatric patients group, bladder debris should be an alerting finding for the diagnosis of urinary tract infection (UTI).

Keywords: Urinary tract infection, urine culture, bladder debris, ultrasonography

\section{Introduction}

Urinary tract infection (UTI) is a common disease in childhood. Diagnosis of UTI is made by observing significant number of bacterial growth in urine culture obtained under appropriate conditions (1). Clinical findings of UTI vary according to age, gender, localization and severity of infection in the urinary tract (2). Clinically, it shows a wide spectrum from asymptomatic bacteria to symptomatic complicated pyelonephritis. Nonspecific findings and sepsis are common in the neonatal period. It also shows nonspecific findings in infants (3). Although, early diagnosis and treatment of UTI is critical, clinical diagnosis is complicated due to nonspecific findings in children. The common view of pediatric nephrologists states that first urinary tract infection, which occurs in the neonatal and early childhood period, is able to leave a permanent renal scar (4). It is reported that $50 \%$ of the patients in the infant and early childhood phase, in whom the cause of fever cannot be diagnosed through clinical examination and $30 \%$ of the girls with a fever of 39 degrees Celcius and above in the period of infancy suffer from UTI (5).

Urinary system ultrasonography (UUSG) is considered as the first step imaging method for children with febrile firsttime and recurrent UTI (6). Ultrasound is often preferred because of its painless, noninvasive, easy applicable and radiation-free features. The purpose of USG is to detect anatomic abnormalities. Moreover, it also provides the evaluation of kidney parenchyma, size and shape (6). Besides the evaluation of both kidneys in UUSG, bladder wall thickness and bladder lumen are also evaluated. Stone, mass, hematoma and debris can be seen in the lumen of the bladder. The appearance of debris consisting of a floating or layering echoing without the increase in thickness of the bladder wall is one of the common findings in the infant and child patient group. The echoes observed in the bladder may be a technical artefact or a real pathology (7). The movement of the Echoes and change of level by gravity indicate that echo in the bladder is not an artefact but a debris (8). Bladder debris may be related to various pathologies such as dehydration, hematuria, infection, and pyuria.
Sonuç: USG'de mesane debrisi izlenen çocuk hastalarda + IK oranında istatistiksel olarak anlamlı artış izlenmektedir. Bu artış seviye oluşturan debrisli hastalarda daha yüksektir. Mesane debrisi çocuk hasta grubunda IYE tanısı açısından uyarıcı olmalıdır.

Anahtar Kelimeler: İdrar yolu enfeksiyonu, mesane debrisi, idrar kültürü, ultrasonografi

The purpose of this study is to investigate the association of bladder debris frequently detected at urinary tract and abdomen ultrasound and UTI diagnosed with + urine culture (UC) on the same day with ultrasound. The first of our hypothesis in the study was that the presence of debris in the bladder shows a meaningful relationship with the UTI. Our second hypothesis was the association of UTI and the fact that layering bladder debris would be higher than floating debris seen at the UUSG of children.

\section{Materials and Methods}

Between February 2017-February 2018, the patient group and control group were selected retrospectively among pediatric patients who underwent ultrasound by single radiologist and device. Ninety-three patients were detected with bladder debris between the ages of 0 and 11. Patients with genitourinary and anatomic disorders such as neurogenic bladder, Vesicoureteral Reflux (VUR), hydronefrosis and patients with recurrent history of UTI were not included in the study. UC and ultrasound of patients were conducted in same day. Patients with bladder debris diagnosed as UTI with clinical findings and urine analysis but not having UC, and patients having contaminated UC were also not included into the study.

Ninety-three patients with bladder debris were classified as layering and floating debris. In Group 1, there were 21 patients with layering debris and there were 72 patients with floating debris in Group 2. The control patient group was retrospectively selected including 50 patients between the ages of 0 and 11. This group was selected from patients without any history of recurrent UTI and without any genitourinary and anatomic disorders. The patients in the control group had normal urinary ultrasound and UC on the same day. The free movement of the echoes and change of level by gravity detected minimum in two different planes indicated that the echo in the bladder was not an artefact but a debris. Urine samples for UC were obtained with a sterile pediatric urine collection bag after perineal cleaning from children who were not toilet trained. In toilet trained children, urine samples for UC was collected form midstream urine samples. Children having clinical signs and symptoms were diagnosed as $\mathrm{UCl}$ if they had 
$>10^{5}$ bacterial colonies in the UC. Twenty-eight children with bladder debris, clinical findings, and + UC was diagnosed as UTI. Seventeen of 28 children had upper UTI diagnosed with clinical and laboratory findings and 11 had lower UTI.

\section{Statistical Analysis}

Ages amongst groups were analyzed with nonparametric Kruskal-Wallis test. Multiple logistic regression analysis was used for UTI association with bladder debris amongst groups. SSPS 15.0 program was used for the analysis with $95 \%$ confidence interval and $p<0.05$ significance level.

\section{Results}

In our study group of bladder with debris, there were 93 patients consisting of 44 boys ( $47.5 \%)$ and 49 girls $(52.5 \%)$ ranging from 0 to 11 years old. Examples of patients with layering and floating debris are shown in Figure 1. In the control group, there were a total of 50 patients consisting of 27 girls (\%54) and 23 boys (46\%) aged between 0-11 years. Mean age of the patients with debris (SD \pm 36.56 ) was 33.52 months, the average age of the control group was 32.52 (SD \pm 34.08 ) months, and statistically no difference was observed between the two groups.

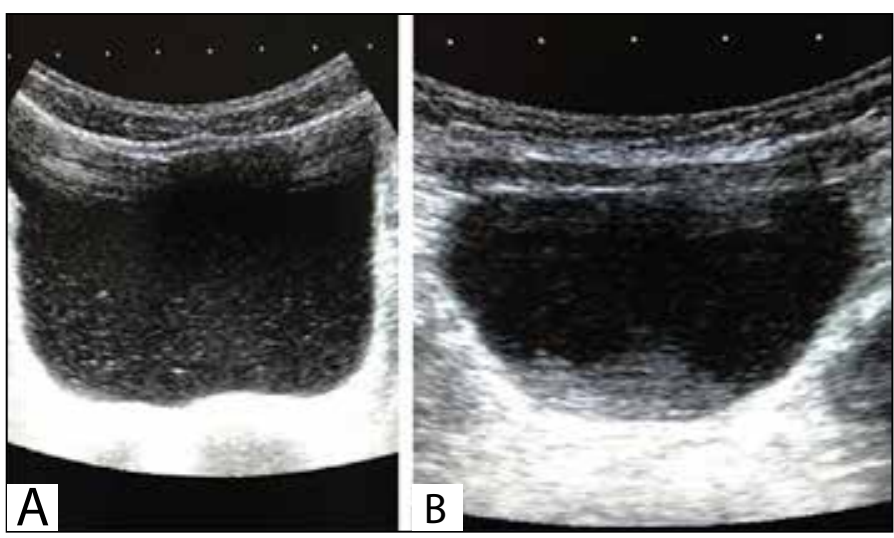

Figure 1. USG images of patients with bladder debris. A: Floating bladder debris, B: Layering bladder debris.
Ninety-three patients with debris were categorized into two groups as patients with layering and floating debris. Group 1 consisted of 21 patients with layering debris and Group 2 consisted of 72 patients with floating debris. In nine of the 21 patients of Group 1, bacterial growth was detected in UC while urine cultures of the remaining 12 patients were normal. In nineteen of the 72 patients in Group 2 bacterial growth was detected in UC while urine cultures of the remaining 52 patients were normal. Moreover, eight UC positivity was detected in the control group of 50 patients whose UUSGs were normal. UC positivity rates and UTI pathogens of the patient group with debris and control patient group are shown in Table 1.

Statistical data obtained with multiple logistic regression analysis are as follows:

There was a statistically significant increase in the positive urine culture of the patients with layering debris compared to the control patient group (OR: 4.295; 95\% Cl 1.345-13.715; $\mathrm{p}<$ 0.05).

Similarly, there was a statistically significant increase in the positive urine culture of the patients with floating debris compared to the control patient group (OR: $1.882 ; 95 \% \mathrm{Cl} 0.750-$ 4.722; $p<0.05)$.

In comparison of the patients with layering and floating debris, increase in the positive urine culture of patients with layering debris was observed (OR: 2.092; 95\% Cl 0.761-5,748; $\mathrm{p}<0.05$ ).

\section{Discussion}

In children, UTI is the second most common infection after upper respiratory tract infection (9). In particular, the symptoms of UTI in infants is not always noticeable, hence it delays early diagnosis and treatment which may cause scar formation in the kidney, hypertension and renal failure. Early diagnosis in UTI may prevent renal scar formation which is a complication of the infection (10). USG can be used as the first step in eval-

Table 1. Urine culture positivity rates and urinary tract infection pathogens of patient with debris and control patient group

\begin{tabular}{|c|c|c|c|}
\hline & \multicolumn{2}{|c|}{ Positive urine culture } & Negative urine culture \\
\hline Bladder debris $(n=93)$ & $28(30 \%)$ & $\begin{array}{c}\text { Escherichia coli (18) } \\
\text { Klebsiella (7) } \\
\text { Proteus (1) } \\
\text { Pseudomonas (1) }\end{array}$ & $65(70 \%)$ \\
\hline Layering bladder debris $(\mathrm{n}=21)$ & $9(42.8 \%)$ & & $12(57.2 \%)$ \\
\hline Floating bladder debris $(n=72)$ & $19(26.3 \%)$ & & $53(73.6 \%)$ \\
\hline
\end{tabular}


Er Ulubaba et al.

uation of the UTI. Bladder wall thickness and bladder lumen are also evaluated by USG beside the kidney dimensions, parenchymal echogenity, stone formation, hydronephrosis, and ureteral dilatation.

Bladder debris is a common finding, but its relation with UTI is not clear. A study has recently been performed on adult patients, but no significant relationship has been noticed between the bladder debris and the UTI. In the mentioned study, patients have been evaluated with urinalysis but UC has not been performed. UTI has been diagnosed in patients with pyuria. Also, urine examination has not been performed on the same day with bladder ultrasound (11).

In pediatric patients, only one study has been made and in that study, patients and the control group have included children undergoing voiding cystourethrography (VCUG). In this study, the urine samples for UC have been collected by urinary catheter and a statistically significant relationship with infection and bladder has been reported. Since VCUG is performed in patients with a history of UTI or suspect of VUR, the study does not represent the common pediatric population $(12,13)$.

Bladder wall thickness and bladder debris have been reported as significant imaging findings of UTI in infants younger than three months of age with bacterial UTI in an other study (14).

The result of our study also supports our two hypotheses. In patients with bladder debris, there was a statistically increase in the rate of $+U C$, and this increase was higher in patients with layering debris. Positive UC rate was $30 \%$ in patients with debris and $16 \%$ in patients without debris. If we categorized the patients with debris as layering and floating debris, it was observed that positive UC rate is $26.3 \%$ in patients with floating debris and $42.8 \%$ in patients with layering debris.

The biggest limitation of our work is that it is a retrospective study and some of the patients with debris were not included into the study although they met the clinical conditions. For example, there were some patients whose UC and USG were not carried out at the same day, and there were some patients who were evaluated with urinalysis instead of UC. This limitation can only be eliminated by conducting a prospective study and having UC at the same day with debris detection. The other limitation of our work is the risk of contamination due to the collection of urine for UC by urine collecting sterile bag method in patients under three years of age who were not toilet trained. This limitation can only be avoided by interventional suprapubic urine aspiration or urine collection with urinary foley catheter. The applicability of the abovementioned urine collecting methods is not suitable for children in outpatient clinics since those methods are interventional. In spite of these limitations, our study is the only study that evaluates the association of urinary bladder debris and UTI in the general pediatric population. We hope our study would be a major milestone and stepping stone for future studies that will be done by reducing the limitations.

\section{Conclusion}

Our study shows that in children aged 0-11 years, the bladder debris detected during the USG is valuable for determining UTI. Especially in pediatric patient group which is asymptomatic and shows nonspecific findings, detection of bladder debris can help for earlier diagnosis of the UTI. Additionally, since the positive UC ratio is higher in patients with layering debris than floating debris, it can be said that layering pattern debris formation is a more sensitive finding in diagnosis of UTI.

Ethics Committe Approval: This research was conducted with the permission of Inonu University Malatya Clinical Research Ethics Committee (decision number of ethics committee permission: 2019/62, dated 06.03.2019).

Informed Consent: Patient concent was obtained.

Peer-review: Externally peer-reviewed.

Author Contributions: Concept - HEU, GMD; Design - HEU, GMD; Supervision - SS, HEU; Materials - HE; Data Collection and/or Processing - HE; Analysis and/or Interpretation - SS; Literature Review - HEU; Writing - HEU, GMD; Critical Review - All of authors.

Conflict of Interest: No conflict of interest was declared by the authors.

Financial Disclosure: The authors declared that this study has received no financial support.

\section{References}

1. Elder JS. Urinary tract infections. In: Behrman RE, Kliegman RM, Jenson $H B$ (eds). Nelson Textbook of Pediatrics. $18^{\text {th }}$ ed. Philadelphia: WB Saunders Company, 2007:2223-8. [CrossRef]

2. Jantausch B, Kher K. Urinary tract infection. In: Kher KK, Schnaper HW, Makker SP (eds). Clinical Pediatric Nephrology. $2^{\text {nd }}$ ed. London: Informa Healthcare, 2006:553-73. [CrossRef]

3. Yılmaz A. Tekrarlayan idrar yolu enfeksiyonu geçiren çocukların retrospektif taranması ve renal skar üzerine etkisinin değerlendirilmesi. Kahramanmaraş: Kahramanmaraş Sütçü İmam Üniversitesi Tıp Fakültesi, 2011. [CrossRef]

4. Babu R, Chowdhary S. Controversies regarding management of vesico-ureteric reflux. Indian J Pediatr 2017;84(7):540-4. [CrossRef].

5. Buyan N. Çocukluk çağında idrar yolu enfeksiyonları. Klinik Pediatri Dergisi 2007;2(2):31-7. [CrossRef]

6. Roberts KB. Urinary tract infection: clinical practice guideline for the diagnosis and management of the initial UTI in febrile infants and children 2 to 24 months. Subcommittee on Urinary Tract Infection, Steering Committee on Quality Improvement and Management. Pediatrics 2011;128:595-610.'[CrossRef],

7. Kirberger RM. Imaging artifacts in diagnostic ultrasound: a review. Vet Radiol Ultrasound 1995;36:297-306. [CrossRef]. 
8. Goldstein A, Madrazo BL. Slice-thickness artifacts in gray-scale ultrasound. J Clin Ultrasound 1981;9:365-75. [ [CrossRef].

9. Lambert $H$. Urinary tract infection in infancy and childhood. In: Turner N, Goldsmith D, Lamiere N, Winearls C, Himmelfarb J, Remuzzi G (eds). Oxford Textbook of Clinical Nephrology. Oxford University Press, 2016:1520-31. [CrossRef]

10. Sirin A, Emre S, Alpay H, Nayir A, Bilge I, Tanman F. Etiology of chronic renal failure in Turkish children. Pediatric Nephrology 1995;9:549-52. "CrossRef]"

11. Cheng SN, Phelps A. Correlating the sonographic finding of echogenic debris in the bladder lumen with urinalysis. J Ultrasound Med 2016;35:1533-40. [CrossRef].
12. McQuaid JW, Kurtz MP, Logvinenko T, Nelson CP. Bladder debris on renal and bladder ultrasound: a significant predictor of positive urine culture. J Pediatr Urol 2017;385:e1-e5. [CrossRef],

13. Stevenson SM, Lau GA, Andolsek WC, Presson AP, Cartwright PC. Bladder debris on ultrasound as a predictor for positive urine culture in a pediatric population. J Pediatr Urol 2018;14:e 1-e5. [CrossRef]"

14. Chang PW, Abidari JM, Shen MW, Greenhow TL, Bendel-Stenzel M, Roman $H K$, et al. Urinary imaging findings in young infants with bacteremic urinary tract infection. Hospital Pediatrics 2016;6:11!"[CrossRef]", 